\title{
Strict insulin therapy normalises organ nitrogen contents and the capacity of urea nitrogen synthesis in experimental diabetes in rats
}

\author{
T.P. Almdal and H. Vilstrup \\ Divisions of Hepatology and Experimental Pathology, Righshospitalet, Copenhagen, Denmark
}

\begin{abstract}
Summary. Rats with experimental diabetes due to streptozotocin $(75 \mathrm{mg} / \mathrm{kg}$ body weight) and free access to food were divided into two groups. One group $(n=9)$ was optimally treated with insulin (glucosuria $<4.0 \mathrm{mmol} / 24 \mathrm{~h}$ ), using heat treated very long-acting ultralente insulin. The other group $(n=10)$ was poorly treated with insulin (glucosuria $20-30 \mathrm{mmol} / 24 \mathrm{~h}$ ).

The nitrogen balance and energy balance of optimally treated diabetic rats was positive and not different from the control group $(n=6)$. In the poorly treated diabetic rats the nitrogen balance was reduced whereas the energy balance was not different from that of control rats. After 4 weeks the fasting glucagon was: $50 \pm 21 \mathrm{ng} / 1$ (mean \pm SEM) in control rats, $62 \pm 18 \mathrm{ng} / 1$ in optimally treated diabetic rats and $249 \pm 58 \mathrm{ng} / \mathrm{l}$ in poorly treated diabetic rats $(p<0.01)$. The capacity of urea nitrogen synthesis determined during alanine loading was: $9.6 \pm 1.0 \mu \mathrm{mol} /(\min 100 \mathrm{~g}$ body weight) in control rats, $10.6 \pm 1.7 \mu \mathrm{mol} /(\min 100 \mathrm{~g}$ body weight) in opti-
\end{abstract}

mally treated diabetic rats and $17.3 \pm 1.3 \mu \mathrm{mol} /(\min 100 \mathrm{~g}$ body weight) in poorly treated diabetic rats $(p<0.01)$.

Nitrogen contents of carcass, heart, intestines, liver, and kidneys as determined by Kjeldahl analyses were identical in control rats and optimally treated diabetic rats. In the poorly treated diabetic rats carcass-nitrogen and heart-nitrogen contents were reduced to $89 \%$ of the control value $(p<0.01)$, whereas the kidney-nitrogen content was increased to $112 \%$ of the control value $(p<0.01)$.

Strict insulin therapy in experimental diabetes leads to a normalisation of nitrogen metabolism and hyperglucagonaemia, whereas less than optimally insulin treated rats show marked abnormalities in nitrogen metabolism as well as hyperglucagonaemia.

Key words: Experimental diabetes, urea synthesis, N-metabolism, $\mathrm{N}$-balance, insulin therapy.
Uncontrolled diabetes mellitus is characterised by a negative nitrogen $(\mathrm{N})$ balance $[1,2]$ and loss of nitrogen from most organ systems [2]. It is assumed, but has never been systematically investigated, that these abnormalities can be totally reversed by means of insulin therapy.

The nitrogen lost from organs in uncontrolled diabetes is excreted as urea and the kinetics of the hepatic urea $\mathrm{N}$-synthesis is changed in experimental diabetes $[2,3]$. Whether this is normalised with insulin treatment is unknown.

Perfect metabolic control is the goal of diabetes treatment. However, in practice many diabetic patients are sub-optimally controlled. Therefore, the effects of both an optimal and a suboptimal insulin treatment regimen on nitrogen metabolism is of interest.

The purpose of the present study was to assess the effects of an optimal and a less than optimal insulin treatment regimen on the $\mathrm{N}$-metabolism, i.e. $\mathrm{N}$-balance, $\mathrm{N}$-contents of organs and the kinetics of the hepatic urea synthesis, in rats with experimental diabetes.

\section{Material and methods}

\section{Animals and diets}

Female Wistar rats with an average initial body weight (BW) of $220 \mathrm{~g}$ were used. Experimental diabetes was induced after an overnight fast by intravenous injection of streptozotocin (Zanosar, Upjohn Co, Kalamazoo, Mich, USA), $75 \mathrm{mg} / \mathrm{kg}$ BW dissolved in isotonic saline acidified to $\mathrm{pH} 4.5$. The control rats received isotonic saline, acidified to $\mathrm{pH} 4.5$.

All animals were housed individually in metabolic cages kept in a thermostated room with a fixed 12 -h artificial light-dark cycle. The rats had free access to water and were fed with pulverised Altromin (Altromin Werke, Lage, FRG) standard diet. The same batch of diet was used throughout the study.

The animals were kept in the cages for a total of 35 days. They were weighed every second day.

On the last 2 days of each week, i.e. days 6 and 7,15 and 16, etc., the amount of food ingested was determined for each animal. Samples of urine were analysed for total nitrogen and urea contents and feces for total nitrogen content. The amount of glucose in urine was determined daily.

From the results obtained on the last two days of each week the nitrogen balance $(\mathrm{N}-\mathrm{bal})(\mathrm{mmol} / 24 \mathrm{~h})$ was calculated for every rat as: 
$\mathrm{N}$-bal $=$ Food $(\mathrm{g}) \times$ food $\mathrm{N}$-concentration $(\mathrm{mmol} / \mathrm{g})-($ urine $\mathrm{N}+$ feces $\mathrm{N}$ contents)

The average nitrogen balance for week 1 , week 2 etc. was then calculated within the three groups of animals investigated. The energy balance (E-bal) were calculated as:

E-bal $=$ Food $(\mathrm{g}) \times$ caloric value $(13 \mathrm{KJ} / \mathrm{g})-$ glucose lost in urine $(\mathrm{mmol}) \times$ caloric value $(2.9 \mathrm{KJ} / \mathrm{g})$

The first week in the cages served as an adaptation period. Initially the rats lost $5-10 \%$ in body weight and ate less, but on day 5 they had regained their initial weight and food intake.

\section{Protocols}

On day 9, after an overnight fast, the animals were randomly allocated to one of the three following protocols:

(1) Controls: Animals given saline and allowed food ad libitum $(n=6)$.

(2) Diabetes optimally controlled ( $D M$ opt): Animals given streptozotocin, allowed food ad libitum, and optimally controlled with insulin (cf below) $(n=9)$.

(3) Diabetes poorly controlled (DM poor): Animals given streptozotocin, allowed food ad libitum and poorly controlled with insulin (cf below) $(n=10)$.

\section{Insulin therapy}

Glucosuria appeared within $24 \mathrm{~h}$ after the administration of streptozotocin. The optimally controlled rats (DM opt) were left without insulin for another $24 \mathrm{~h}$, in order to ascertain the diabetic state (glucosuria $>30 \mathrm{mmol} / 24 \mathrm{~h}$ ). Then insulin therapy was started, using a long-acting insulin preparation, heat treated Insulin Ultralente bovine, $\mathrm{pH} 5.5$ (NOVO Industries, Copenhagen, Denmark) [4, 5]. Initially, $8 \mathrm{IU}$ of insulin per day were given and within the first week was gradually reduced to $4 \mathrm{IU}$ per day. Then the dosage was adjusted according to blood glucose values determined daily with Dextrostix and Ames Reflectometer. Blood glucose values between 3.0 and $7.0 \mathrm{mmol} / \mathrm{I}$ were accepted without leading to changes in the insulin dosage. After 10 days on this regimen the insulin dosage stabilised at about $5 \mathrm{IU}$ per $24 \mathrm{~h}$.

The poorly controlled diabetic rats (DM poor) were left without insulin for 4 days before the insulin treatment was started. Insulin dosage was then adjusted according to daily measurements of glucosuria, aiming at a glucose excretion of $10-30 \mathrm{mmol} / 24 \mathrm{~h}$. The mean insulin dosage was about $2 \mathrm{IU}$ per $24 \mathrm{~h}$. There was no ketonuria.

\section{$N$-contrent of organs}

Following determinations of the capacity of urea-N synthesis, (cf. below), the animals were bled via the aortic bifurcature. Following dissection the following organs were isolated and weighed: kidneys, liver, heart, intestines, and carcass (comprising muscles, bones and nervous system). Intestines and carcass were homogenised in sterile water by means of a food processor and samples were frozen for analysis. The kidneys, livers, and hearts were frozen in toto.

\section{Analyses}

The blood urea concentration was measured by the urease-Berthelot method [6] and the total alpha-amino- $\mathrm{N}$ by the dinitrofluorobenzene method [7]. The glucose concentration in blood and in urine was measured by the glucose oxidase technique, using a rapid glucose analyser (Yellow Springs Instruments, Yellow Springs, Ohio, USA). Plasma insulin and glucagon concentrations were determined by radio-immunoassay $[8,9]$, glucagon after ethanol extraction.

$\mathrm{N}$-contents in excreta and in organs were determined by micro Kjeldahl technique as previously described [2].

\section{The capacity of the urea- $N$ synthesis (CUNS)}

On day 36, after an overnight fast the rats were anaesthetised by thiopental, $50 \mathrm{mg} / \mathrm{kg}$ body weight i.p., tracheotomised, and nephrectomised. Polyethylene catheters were inserted into a jugular vein for infusion and into a common carotic artery for blood sampling.

Alanine was administered as a priming dose of $0.4-0.7 \mathrm{ml}$ of a $1009 \mathrm{mmol} / \mathrm{l}$ solution in sterile water followed by a constant infusion of $2.0-3.5 \mathrm{ml} / \mathrm{h}$ of a $224 \mathrm{mmol} / 1$ solution by means of a roller pump (Perfursor Secura, Braun, Melsungen, FRG). Steady state amino acid concentration was defined as less than $10 \%$ change during at least $50 \mathrm{~min}$. The amino acid administration were adjusted so as to obtain steady state within the amino acid concentration interval $7.6-11.3 \mathrm{mmol} / 1$, where the urea synthesis is at maximum $[3,10]$, i.e. saturated and thus substrate concentration independent.

After an initial equilibration period of $20 \mathrm{~min}$, blood was sampled $(100 \mu \mathrm{l})$ at intervals of $10 \mathrm{~min}$ for determination of total alphaamino- $\mathrm{N}$ and urea. CUNS was calculated as the accumulation rate of urea in the urea space, corrected for intestinal hydrolysis:

$\mathrm{CUNS}=\mathrm{dcu} / \mathrm{dt} \times 0.63 \times \mathrm{BW} \times(1-0.20)$

where $\mathrm{dcu} / \mathrm{dt}$ is the slope of the linear regression analysis on time, 0.63 is the distribution volume of urea (identical in normal and in diabetic rats [3]) and 1-0.20 is the fractional intestinal hydrolysis of newly synthesised urea (identical in normal and in diabetic rats [3, 10]).

\section{Statistical analysis}

Differences between two groups were evaluated by Student's t-tests. Differences between more than two groups were tested by one way analysis of the variance. cant.

$p$ values smaller than 0.05 werer considered statistically signifi-

\section{Results}

Both groups of diabetic animals had a glucose excretion of about $40 \mathrm{mmol} / 24 \mathrm{~h}$ before starting insulin therapy. On insulin therapy the glucose excretion of the optimally controlled diabetic rats was reduced to an average of $3.8 \pm 1.0 \mathrm{mmol} / 24 \mathrm{~h}$ (mean $\pm \mathrm{SEM}$ ). The poorly controlled diabetic animals had an average glu-

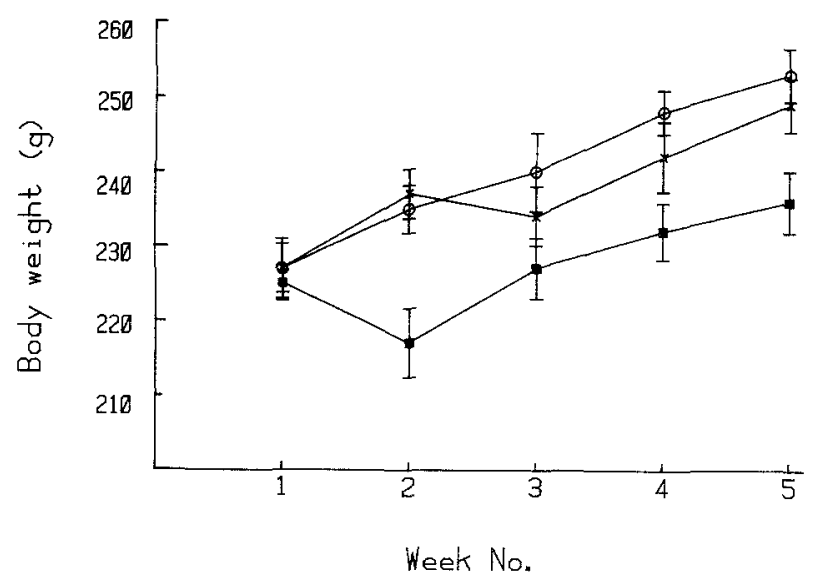

Fig. 1. The development in body weight in control rats $(O)$, diabetic rats optimally controlled with insulin (x) and diabetic rats poorly controlled with insulin ( $\mathbf{\square})$. Results are given as mean with $95 \%$ confidence limits 
Table 1. Nitrogen (N) contents of carcass, heart, intestine, liver and kidneys from control rats (control), diabetic rats optimally controlled with insulin for 4 weeks (diabetes optimally controlled) and diabetic rats poorly controlled with insulin for 4 weeks (diabetes poorly controlled). Results are mean \pm SEM

\begin{tabular}{|c|c|c|c|}
\hline & $\begin{array}{l}\text { Control } \\
(n=6)\end{array}$ & $\begin{array}{l}\text { Diabetes op- } \\
\text { timally con- } \\
\text { trolled }(n=9)\end{array}$ & $\begin{array}{l}\text { Diabetes poorly } \\
\text { controlled } \\
(n=10)\end{array}$ \\
\hline $\begin{array}{l}\text { Carcass } \mathrm{N} \\
(\mathrm{mmol})\end{array}$ & $359 \pm 11$ & $360 \pm 10$ & $318 \pm 8^{a}$ \\
\hline Heart N (mmol) & $1.53 \pm 0.06$ & $1.46 \pm 0.04$ & $1.34 \pm 0.06^{\mathrm{b}}$ \\
\hline $\begin{array}{l}\text { Intestine } N \\
\text { (mmol) }\end{array}$ & $29.1 \pm 0.9$ & $30.3 \pm 0.8$ & $32.7 \pm 1.3$ \\
\hline Liver N (mmol) & $16.7 \pm 0.4$ & $18.6 \pm 0.6$ & $18.1 \pm 0.6$ \\
\hline $\begin{array}{l}\text { Kidney N } \\
\text { (mmol) }\end{array}$ & $3.11 \pm 0.12$ & $3.20 \pm 0.13$ & $3.68 \pm 0.13^{c}$ \\
\hline
\end{tabular}

a Diabetes poorly controlled smaller than controls and diabetes optimally controlled $(p<0.01){ }^{\mathrm{b}}$ Diabetes poorly controlled smaller than controls $(p<0.05)$. ${ }^{c}$ Diabetes poorly controlled higher than controls and diabetes optimally controlled $(p<0.01)$

Table 2. Insulin and glucagon concentrations before starting and at end of alanine infusion in control rats, diabetic rats optimally controlled with insulin for 4 weeks (diabetes optimally controlled) and diabetic rats poorly controlled with insulin for 4 weeks (diabetes poorly controlled). Results are mean \pm SEM

\begin{tabular}{llcc}
\hline & $\begin{array}{l}\text { Control } \\
(n=6)\end{array}$ & $\begin{array}{l}\text { Diabetes op- } \\
\text { timally con- } \\
\text { trolled }(n=9)\end{array}$ & $\begin{array}{l}\text { Diabetes poorly } \\
\text { controlled } \\
(n=10)\end{array}$ \\
\hline $\begin{array}{l}\text { Insulin, start } \\
(\mathrm{mU} / \mathrm{ml})\end{array}$ & $17.5 \pm 4.4$ & $32.1 \pm 5.6$ & $8.9 \pm 2.1$ \\
$\begin{array}{l}\text { Insulin, end } \\
(\mathrm{mU} / \mathrm{ml})\end{array}$ & $38.2 \pm 8.2$ & $24.6 \pm 4.8$ & $13.2 \pm 4.3$ \\
$\begin{array}{l}\text { Glucagon, start } \\
(\mathrm{pg} / \mathrm{ml})\end{array}$ & $50 \pm 21$ & $62 \pm 18$ & $249 \pm 58$ \\
$\begin{array}{l}\text { Glucagon, end } \\
(\mathrm{pg} / \mathrm{ml})\end{array}$ & $476 \pm 143$ & $443 \pm 82$ & $492 \pm 89$ \\
\hline
\end{tabular}

Table 3. The fasting glucose concentration and the glucose concentration at the end of alanine infusion, fasting alpha-amino-N (A-A$\mathrm{N}$ ) and the capacity of urea-N synthesis (CUNS) in control rats, diabetic rats optimally controlled with insulin for 4 weeks (diabetes optimally controlled) and diabetic rats poorly controlled with insulin for 4 weeks (diabetes poorly controlled). Results are mean \pm SEM

\begin{tabular}{llll}
\hline & $\begin{array}{l}\text { Control } \\
(n=6)\end{array}$ & $\begin{array}{l}\text { Diabetes op- } \\
\text { timally con- } \\
\text { trolled }(n=9)\end{array}$ & $\begin{array}{l}\text { Diabetes poorly } \\
\text { controlled } \\
(n=10)\end{array}$ \\
\hline $\begin{array}{l}\text { Glucose, fasting } \\
\text { (mmol/1) }\end{array}$ & $4.8 \pm 0.5$ & $6.5 \pm 1.3$ & $11.5 \pm 1.3^{\mathrm{a}}$ \\
$\begin{array}{l}\text { Glucose, end } \\
(\mathrm{mmol} / \mathrm{l})\end{array}$ & $9.5 \pm 0.9$ & $11.8 \pm 2.6$ & $26.7 \pm 3.1^{\mathrm{a}}$ \\
$\begin{array}{l}\mathrm{A}-\mathrm{A}-\mathrm{N}, \text { fasting } \\
(\mathrm{mmol} / \mathrm{l})\end{array}$ & $5.4 \pm 0.6$ & $5.3 \pm 0.3$ & $5.2 \pm 0.4$ \\
$\begin{array}{l}\mathrm{CUNS} \\
(\mu \mathrm{mol} / \mathrm{min}\end{array}$ & $9.6 \pm 1.0$ & $10.6 \pm 1.7$ & $17.3 \pm 1.3^{\mathrm{a}}$ \\
\begin{tabular}{l}
$100 \mathrm{~g} \mathrm{BW})$ \\
\hline
\end{tabular} & & & \\
\hline
\end{tabular}

a Diabetes poorly controlled higher than controls and diabetes optimally controlled $(p<0.01)$

cose excretion of $26.5 \pm 1.0 \mathrm{mmol} / 24 \mathrm{~h}$ during insulin treatment.

The optimally insulin treated rats gained about $6 \mathrm{~g} /$ week (Fig. 1) as did the control rats. The poorly con-

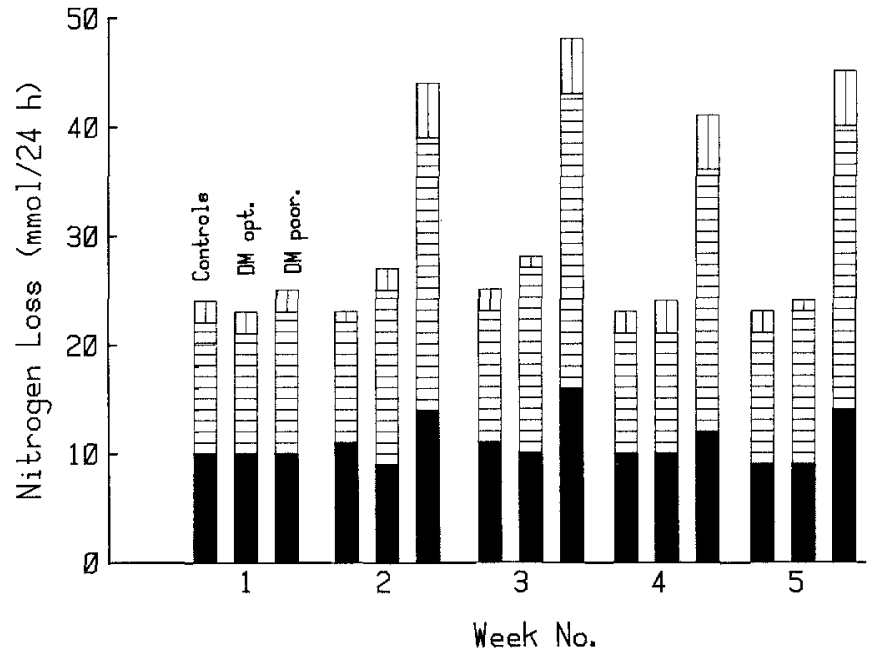

Fig. 2. The amount of nitrogen lost in feces ( $\square)$, as urea (目) and as

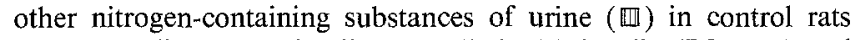
(controls), diabetic optimally controlled with insulin (DM opt) and diabetic rats poorly controlled with insulin (DM poor). Results are given as mean with $95 \%$ confidence limits

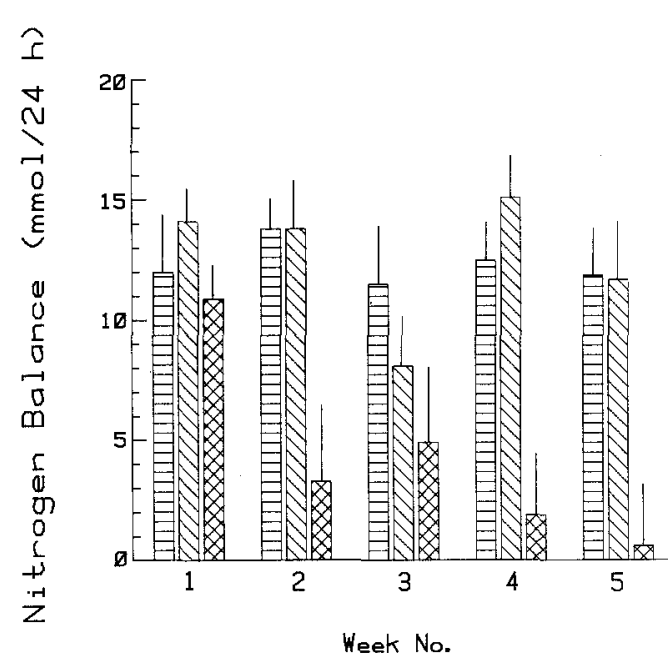

Fig. 3. The calculated nitrogen balance of control rats (目), diabetic optimally controlled with insulin ( $\mathbb{S}$ ) and diabetic rats poorly controlled with insulin (图). Results are given as mean with $95 \%$ confidence limits

trolled diabetic rats initially lost $10 \mathrm{~g}$ in weight and thereafter gained $5 \mathrm{~g}$ /week.

The control rats and the optimally controlled diabetic rats had a constant food intake of about $18 \mathrm{~g} /$ $24 \mathrm{~h}$, whereas the poorly controlled diabetic rats during the course of two weeks increased their food intake to about $24 \mathrm{~g} / 24 \mathrm{~h}$, whereafter it remained constant.

The organ $\mathrm{N}$-contents of control and optimally treated diabetic rats were identical (Table 1). The carcass- $\mathrm{N}$ and the heart- $\mathrm{N}$ contents of the poorly treated diabetic animals decreased to $89 \%$, whereas the kidney- $\mathrm{N}$ contents increased to $112 \%$ (Table 1 ).

The fasting insulin concentrations after 35 days of neither of the two groups of diabetic rats were statistically different from that of control rats (Table 2). Following alanine loading the insulin concentration dou- 
bled $(p<0.05)$ in the control rats but did not change in any of the two groups of diabetic rats. The fasting glucagon concentration of the optimally treated diabetic rats were not different from control values (Table 2), but increased 4 to 5 -fold in the poorly controlled diabetic rats.

The fasting blood glucose concentration of the optimally treated diabetic rats was not different from that of the control rats (Table 3 ) and increased identically following alanine loading. The fasting blood glucose of the poorly controlled diabetic rats doubled and increased more than in the controls during alanine loading.

The fasting blood total alpha-amino- $\mathrm{N}$ concentrations were not different among the three groups (Table 3).

The capacity of urea- $\mathrm{N}$ synthesis was the same in control and optimally controlled diabetic rats, whereas it increased by $75 \%$ in the poorly controlled diabetic rats $(p<0.01$, Table 3$)$.

In the control rats and in the optimally controlled diabetic rats the $\mathrm{N}$-loss was constant and identical throughout the study. Fifty percent was excreted as urea- $\mathrm{N}, 10 \%$ as non-urea $\mathrm{N}$ of the urine, and $40 \%$ as feces $\mathrm{N}$ (Fig. 2). The total N-loss of the poorly controlled diabetic rats nearly doubled, $60 \%$ of the N-loss was urea, $10 \%$ was non-urea of the urine, and $30 \%$ was feces $\mathrm{N}$.

The N-balance of the control rats and the optimally controlled diabetic rats was constantly positive and not systematically different throughout the study (Fig.3). The N-balance of the poorly controlled diabetic rats reduced to near neutral values.

The energy balance of all 3 groups of rats was constant at about $240 \mathrm{KJ} / 24 \mathrm{~h}$ and without any changes in any of the groups throughout the study.

\section{Discussion}

This study shows that intensive insulin treatment normalises the $\mathrm{N}$-metabolism in experimental diabetes, whereas less than optimally insulin treated diabetic animals still have major abnormalities in the N-metabolism.

The very long-acting ultralente insulin preparation has earlier been demonstrated to be superior in the treatment of experimental diabetes [4]. Accordingly, the mean glucose excretion of the optimally treated diabetic animals was as low as reported originally [4], and the fasting glucose concentration as well as the glucose concentration following alanine loading of these animals were normal. The poorly controlled animals were given an amount of insulin which reduced the glucosuria to about $30 \%$ of that seen in uncontrolled diabetes [2]. The animals maintained a near normal body weight on that regimen.

The maintenance and/or increase of the protein contents of any organ depend on the balance between protein synthesis and breakdown. Both processes are influenced by insulin [11]. The intensive insulin treatment of diabetic animals resulted in a normal balance between these processes as reflected in the normal nitrogen content in skeletal muscles and in the heart. Animals given less than optimal insulin treatment have decreased nitrogen contents in these organs. In vivo studies have demonstrated that short term insulin treatment results in a partial normalisation of the protein synthesis of the skeletal muscles and the heart [12] and that complete normalisation of the protein synthesis on a short term basis requires infusion of insulin to concentrations 4 to 5 -fold as high as that seen in control rats [13]. The excretion of 3-methyl histidine, which is assumed to be released on myofibrillar breakdown, was normalised in rats given insulin to a metabolic control similar to that of the poorly controlled diabetic rats in the present study [14], suggesting that degradation is more sensitive to insulin than synthesis. However, in vitro studies have demonstrated that higher concentrations of insulin are required to maximally inhibit protein degradation than to maximally stimulate protein synthesis [15]. The net result of intensive insulin treatment on these two processes is a normalisation of protein contents, whereas the result of poor control is decreased protein content. The poorly treated diabetic animals had a near normal body weight and were even able to increase their weights. The results, therefore, imply that substantial changes in body nitrogen contents and distribution may develop, despite near normal body weight.

In uncontrolled diabetic rats the kidney- $\mathrm{N}$ content was not different from that of control rats [2]. The present study shows that poorly controlled diabetic rats have an increased kidney nitrogen content, whereas optimally controlled rats have a normal nitrogen content of the kidneys. This is in accordance with the increased weight of the kidneys in poorly controlled diabetic rats reported earlier [15]. This has been ascribed to a normal synthesis and decreased breakdown, but few experimental details are given [16].

The strict insulin treatment normalised glucagon whereas the poorly controlled diabetic rats had a marked hyperglucagonaemia. In patients normalisation of diabetic hyperglucagonaemia requires strict metabolic control by means of an insulin infusion pump [17]; whereas conventional treatment with two daily insulin injections, even administered aggressively, does not completely abolish the hyperglucagonaemia [18].

One major effect of the hyperglucagonaemia is probably to increase the urea synthesis capacity [2]. However, insulin in itself decreases CUNS [19] so that an effect of insulin on CUNS can not be excluded in the optimally controlled diabetic animals.

The poorly controlled diabetic animals had a CUNS twice as high as the control rats. This implies that these rats at any given amino acid concentration 
convert twice as much as normal amino- $\mathrm{N}$ to urea. The poorly controlled and the control animals had identical fasting values of amino- $\mathrm{N}$, and accordingly excreted twice as much urea.

The energy balances were not different among the three groups of animals, hence the loss of nitrogen was not secondary to a decreased energy availability.

In conclusion, the present study demonstrates that strict insulin therapy in experimental diabetes normalises $\mathrm{N}$-metabolism as well as hyperglucagonaemia. Moreover, diabetic rats given less insulin than optimally, but enough to ensure near normal growth have substantial changes in N-metabolism as evidenced by a less positive $\mathrm{N}$-balance, loss of $\mathrm{N}$ from muscles and heart, and changed kinetics of the hepatic amino- $\mathrm{N}$ conversion, as well as marked hyperglucagonaemia.

Many diabetic patients, insulin-dependent as well as non-insulin-dependent, even in good metabolic control have hyperglucagonaemia. The present study indicates that such patients may still have significant disturbances in their $\mathrm{N}$-metabolism, leading to protein wasting partly via an accelerated hepatic amino- $\mathrm{N}$ conversion.

Acknowledgements. The skillful assistance of technicians B. Krog, L. Hansen and K. Prisholm, I. Petersen, B. Fich and E. Nietsch are hereby greatfully acknowledged. Our thanks are due to technician A. Lieth, Department of Clinical Chemistry, Rigshospitalet, who kindly performed the analysis of the urine urea. This study was supported by grants from The Danish Foundations for the Advancements of Medical Science, The Danish Hospital Foundation for Medical Research Region of Copenhagen, The Faeroe Islands and Greenland, The P.Carl Petersen Foundations and the King Christian $\mathrm{X}$ Foundation.

\section{References}

1. Atchley DW, Loeb RF, Richardson DW, Benedict EM, Driscoll ME (1933) On diabetic acidosis. J Clin Invest 12: 297-326

2. Almdal T \& Vilstrup H (1987) Effects of streptozotocin-induced diabetes and diets on the nitrogen loss from organs in diabetes. Diabetologia 30: 952-952

3. Almdal T, Petersen KF, Hansen BA \& Vilstrup H (1986) Increased capacity of urea synthesis in experimental diabetes in rats. Diabetologia 29: 812-816

4. Rasch R (1979) Control of blood glucose levels in the streptozotocin diabetic rat using a long-acting heat-treated insulin. Diabetologia 16: 185-190
5. Jacobsen J (1979) Early and preventable changes of peripheral nerve structure and function in insulin-deficient diabetic rats. $J$ Neurol Neurosurg Psychiatry 42: 509-518

6. Fawcett JK, Scot JE (1960) A rapid and precise method for determination of urea. J Clin Pathol 13: 156-159

7. Goodwin JF (1970) Spectophotometric quantitation of plasma and urinary amino nitrogen with fluorodinitrobenzene. Stand Meth Clin Chem 6:89-98

8. Ørskov H, Yde H, Thomsen HC (1968) Wick-chromatography for rapid and reliable immuno assay of insulin, glucagon and growth hormone. Nature 219: 193-195

9. Heding LG (1971) Radioimmunological determination of pancreatic and gut glucagon in plasma. Diabetologia 7:10-17

10. Hansen BA, Vilstrup H (1985) A method for determination of the capacity of urea synthesis in the rapid. Scand J Clin Lab Invest 45: $315-320$

11. Jefferson LS, Li BJ, Rannels RS (1977) Regulation by insulin of amino acid release and protein turnover in the perfused rat hemicorpus. J Biol Chem 252: 1476-1483

12. Pain VM, Garlick PJ (1974) Effects of streptozotocin diabetes and insulin treatment on the rate of protein synthesis in tissues of the rat in vivo. J Biol Chem 249: 4510-4514

13. Odedra B, Dalal SS \& Millward DJ (1982) Muscle protein synthesis in the streptozotocin-diabetic rat. Biochem $\mathbf{J} 202: 363-368$

14. Naakhooda AF, Wei C-N, Marliss EB (1980) Muscle protein catabolism in diabetes: 3-Methylhistidine excretion in the spontaneous diabetic "BB" rat. Metabolism 25: 1272-1277

15. Jensen PK, Sandahl Christensen J, Steven K, Parving H-H (1981) Renal function in streptozotocin diabetic rats. Diabetologia 21: 409-414

16. Garlick PJ, Albertse EC, McNorlan MA, Pain VM (1981) Protein turnover in tissues of diabetic rats. Acta Biol Med Ger 40: 1301-1307

17. Raskin P, Pietri A, Unger R (1979) Changes in glucagon levels after four to five weks of glucoregulation by portable insulin infusion pumps. Diabetes 28: 1033-1035

18. Raskin P, Unger P (1978) Effects of insulin therapy on the profiles of plasma immunoreactive glucagon in juvenile-type and adult-type diabetes. Diabetes 27: 411-419

20. Hansen BA, Krog B, Vilstrup H (1986) Insulin and glucose decreases the capacity of urea- $\mathrm{N}$ synthesis in the rat. Scand J Clin Lab Invest 46: 599-603

Received: 1 September 1987

and in revised form: 11 December 1987

Dr. Thomas Almdal

Medical Department A-2151

Rigshospitalet

9 Blegdamsvej

DK-2100 Copenhagen

Denmark 